\title{
Organizational Determinants of Workplace Deviant Behaviours: An Empirical Analysis in Nigeria
}

\author{
Bamikole. O. Fagbohungbe \\ Department of Psychology, University of Lagos \\ Lagos, Nigeria \\ E-mail: kolefagbo@yahoo.com
}

Gabriel A. Akinbode (Correspondent author)

Department of Psychology, University of Lagos

Lagos, Nigeria

Tel: 234-802-310-7609Ｅ-mail: bodegabriel@yahoo.com

Folusho Ayodeji

Department of Psychology, University of Lagos

Lagos, Nigeria

E-mail: folusho2000ng@yahoo.com

Received: November 17, 2011

Accepted: January 29, 2012

Published: March 1, 2012

doi:10.5539/ijbm.v7n5p207

URL: http://dx.doi.org/10.5539/ijbm.v7n5p207

\begin{abstract}
This study examines the relationship between employee's organizational reactions and deviant behaviours in the workplace. Drawing on the organizational climate and workplace deviance literatures, we hypothesize that deviant workplace behaviours of males will be significantly different from that of their female counterpart. Likewise, that there will be a significant positive relationship between employees organisational reactions and various facets of deviant behaviour in the workplace. The study was anchored on Affective Events Theory, Agency Theory and Robinson \& Bennett Typology of Deviance behaviour Theory. Six hundred and ninety six employees completed the surveys. The results supported our hypotheses. First, male participants were significantly different from their female counterparts on production deviance, personal aggression, political deviance and property deviance respectively. Specifically, production deviance, personal aggression and political deviance were higher among females than males. Second, multiple regression analysis revealed that organisational reaction variables (supervision, company identification, kinds of work, amount of work, co-workers, physical work conditions and financial rewards) are significant predictors of different facets of workplace deviant behaviours among workers. Finally, mean deviant behaviours of males at both controlled work environment and less controlled work environment was higher and significantly different from that of their female counterparts. Interaction between gender and work environment control was not significant as expected. The results were discussed in the light of extant literature on deviant workplace behavior, and implications for management practices.
\end{abstract}

Keywords: Organisational reactions, Deviant behaviours, Management control

\section{Introduction}

Unethical and deviant workplace behaviour is becoming a prevalent problem in organisation. It is estimated that between 33 and 75 percent of all employees have engaged in aggressive behaviours such as theft, fraud, vandalism, and sabotage (Harper, 1990). Less prevalent, yet still harmful, are aggressive behaviours such as lying (DePaulo \& DePaulo, 1989), spreading rumours (Skarlicki \& Folger, 1997; Fox \& Spector, 1999), withholding effort (Kidwell and Bennett, 1993) and absenteeism (Johns, 1997). These attitudes violate 
workplace norms and therefore are considered to be an antisocial type of behaviour (Robinson and Bennett, 1995). It is therefore not surprising that organizational scholars have focused, with vigour, on various forms of negative behaviours in the workplace in recent times (Fox \& Spector, 1999; Fisher, 2003; Griffin \& Lopez, 2005). Notable examples of these behaviors include deviance, aggression, antisocial behaviour, and violence.

Employee theft, fraud and sabotage, as well as playing mean pranks, acting rudely, and arguing have been suspected to be the fastest growing deviance workplace behaviours among Nigerian workgroups in recent times. Indeed, the impetus for the growing interest in workplace deviance behaviours is obvious considering the increasing prevalence of this type of behaviour in the workplace and the enormous economic and social costs associated with such behaviours (Fisher, 2002; Robinson \& Benneth, 1995; Peterson, 2002, Galperin \& Burke, 2006, Akinbode 2009). Today, workplace deviant behaviour has become an important concern for organization and a topic of increasing research attention (Bennett \& Robinson, 2003). Several studies in the recent past have documented not only the financial impact it, but also the social and psychological effects of negative workplace behaviour on the organization (Hollinger \& Clark, 1982; Hollinger \& Clark, 1983; Murphy, 1993). Therefore, the prevalence of workplace deviance and its associated organizational costs necessitate a specific, systematic, theoretically focused program of study into this behaviour. To date, relatively little empirical research has directly addressed this generally misunderstood and neglected side of employee behaviour (Vardi \& Wiener, 1996). Over the years, organisational behaviour literature has shown a disproportionate emphasis on desirable phenomenon such as organisational citizenship behaviour (Organ, 1988; Commitment (Mowday, Porter, \& Steers, 1982) and adaptation (Hulin, 1991).

\section{Purpose of the Study}

This study sets out:

(i) to contribute to knowledge in the emerging literature on the subject matter of organisational behaviour, especially negative workplace behaviour.

(ii) to uncover the relationship between organizational reaction and deviance behaviours in the workplace.

\section{Significance of the Study}

The prevalence and costs of misconduct or deviance in the workplace make its study imperative. In an earlier study, it was found that $33 \%$ to $75 \%$ of workers have engaged in behaviours such as vandalism, sabotage, unwanted absenteeism, and outright theft (Harper, 1990). It is very likely that the increasing tension in organizations that resulted from economic changes, increasing global competiveness, and trends toward downsizing and restructuring, will lead to significant misconducts in the workplace. Given that much of the subject matter of organisational misbehaviour had been generally misunderstood and neglected in the past, empirical analysis of remote and immediate cause of organisational misconducts should be a matter of serious concern. Therefore, this study offers a considerable intellectual challenge to industrial/organisational psychologists, HR practitioners, and indeed for effective management practice.

\section{Workplace Deviance: Theoretical and Empirical Review}

Workplace deviance refers to voluntary behaviors by employees that violate significant organizational norms, policies, or rules and in so doing threaten the well-being of the organization and/or its members or both (Robinson and Bennett, 1995). Workplace deviance also can be described as the deliberate or intentional desire to cause harm to an organization (Omar, Halim, Zainah, Farhadi, Nasir \& Kairudin 2011). Examples of workplace deviance include both behaviours directed at organizations (e.g., theft, sabotage, aggression, absenteeism, violence, coming to work late, and putting little effort into work) and individuals in the workplace, such as supervisors or coworkers (e.g., making fun of others, playing mean pranks, acting rudely, arguing). Such behavior at work had received much broadcast play and media ink over the past several years (Kidwell \& Martin, 2004). This notoriety is often due to the sensational negative consequences associated with improper behavior in organizations: financial ruin of many rank-and-file workers due to illegal actions by corporate managers, multiple murders and other violence committed by employees in the workplace, and expensive sexual harassment verdicts. It would be difficult, if not impossible, to produce a truly accurate estimate of the cost of deviant behavior in the workplace, particularly when one includes its many forms - corporate fraud, employee theft, bullying and harassment, revenge, withholding job effort, drug and alcohol abuse, and violence - and the measures taken to prevent and correct them. Yet total estimates in the billions of dollars are routine (Bennett \& Robinson, 2003).

Until recently, workplace deviance has been a neglected topic in organizational research (Greenberg \& Scott, 1996). Instead, researchers emphasize behaviors such as organizational citizenship behavior or contextual 
performance that result in positive outcomes for organizations. However, attention is turning to the study of behaviors at the other end of the spectrum because of their increasing prevalence and detrimental effects on organizations. Bennett and Robinson (2003) showed that the existence of three distinct research trends: (a) studies in which deviance is conceptualized as a reaction to experiences at work, (b) studies that examine deviance as a reflection of employees' personality, and (c) studies that investigate deviance as adaptation to the social context at work.

A few researches have suggested a wide range of reasons why employees engage in deviant behavior. Such studies include; negative job cognition (Lee \& Allen, 2002), perceiving injustice (Aquino, Lewis, \& Bradfield, 1999; Fisher, 2000; Fox, Spector, \& Miles, 2001), negative affectivity (Skarlicki, Folger, \& Tesluk, 1999), hostile attribution, trait anger, attitude revenge (Douglas \& Martinko, 2001). These factors are positively related to the workplace deviant behavior (Skarlicki, Folger, \& Tesluk, 1999; Douglas \& Martinko, 2001; Fox, Spector, \& Miles, 2001).

Robinson and Bennett (1995) used the multidimensional scaling technique to classify workplace deviant behavior. There were two types of deviances; whether the deviance was directed or targeted at either the organization (organizational deviance) or at members of the organization (interpersonal deviance). The first type, organizational deviance refers to deviant behaviors targeting the organization such as theft, sabotage, being late to work or leave early, or withdraw effort from work. The second type, interpersonal deviance refers to deviant acts toward co-workers, supervisors, and subordinates in the workplace. They include expressing behaviors like making fun of others, acting rudely, arguing, and physical aggression. Both are destructive and lead to unfavorable outcomes. These two behaviors may occur simultaneously, singly or even sequentially. In their study, they also proposed adopting different means to overcome the two kinds of deviant behaviors. Interpersonal deviance may serve social functions for organization members such as building group cohesiveness. Organizational deviance, on the other hand may build up signaling functions. To sum, only if we find out the trigger, can we resolve the dysfunctional behaviors

\section{Theoretical Framework}

Affective Events Theory (AET): Affective Events Theory is a model developed by organizational psychologists Weiss and Cropanzano (1996) to identify how emotions and moods influence job performance and job satisfaction. AET proposes that organizational events are proximal causes of effective reactions. By implication, "things happen to people in work setting and people often react emotionally to these events (Weiss \& Cropanzano, 1996). Research in recent times has suggested the hypothesized relationship between moment-to-moment emotions and outcomes such as job satisfaction, organizational commitment and intention to quit (Fisher, 1998). The model increases the understanding of links between employees and their emotional reactions to things that happen to them at work. Work modeled includes hassles, autonomy, job demands, and emotional labour and uplifting actions of their reactions. This emotional response intensity therefore affects job performance and satisfaction. The theory suggests that affect or mood on the job' is an important component of job attitudes and an important predictor of some job behaviours (Brief \& Weiss, 2002; George, 1989; George \& Brief, 1992; Weiss, 2002; Weiss \& Cropanzano, 1996).

Affective events theory also proposes that stable work features such as job scope predisposes the occurrence of certain types of affect producing events. For instance, an enriched job might more often lead to events involving feedback, task accomplishment, and optimal challenge such as may lead to the emotions of pride, happiness and enthusiasm. Information about empirical relations among these variables at work has come primarily from studies using traditional between-persons correlational approaches. However, given the temporal fluctuations in mood on the job, such between-persons approaches may miss much of the variability in moods and job behaviours and obscure relations between them. Studies testing theoretical hypotheses about job affect--behaviour relationships using day-to-day and hour-to-hour fluctuations in mood and behaviours are a needed supplement to between-persons findings.

Agency theory: Agency theory holds that agents (employees) are self-interested individuals who are prone to opportunism. Opportunism relates to furthering one's immediate interests without regard to basic principles or consequences, therefore self-interest of rational individuals does not necessarily result in opportunistic behaviours (Gomez-Mejia, Wiseman, \& Dykes, 2005). There are two ways by which an agent's opportunistic behaviours can be reduced: (1) contracting on the outcome of agent's behaviour by using a performance related compensation system; and (2) creating governance mechanism that closely monitor agent's behaviour and thus increases the chances of detection and punishment. These agency theory's postulates could explain employees' behaviours whenever fraud and counter-productive behaviour are concerned, as evidenced in this study. 


\section{Typology of deviant workplace behaviours}

Robinson and Bennett's (1995) typology of deviant workplace behaviours using multidimensional scaling techniques explains two major (or four types) which are organization wise and interpersonal wise. Under organisational wise are:

(i) production deviance- such as leaving early, taking excessive breaks, intentionally working slow, and wasting resources

(ii) property deviance- such as sabotaging equipment, accepting kickbacks, lying about hours worked, and stealing from company.

Under interpersonal-wise are:

(i) political deviance -such as favouritism, gossiping about co-workers, blaming coworkers, and competing non-beneficially; and

(ii) personal aggression -such as sexual harassment, verbal abuse, stealing from co-workers, and endangering coworkers.

In this same study (Robinson \& Benneth, 1995) results suggest that deviant workplace behaviors do not only vary along these two dimensions but that employee deviance appears to fall into four distinct categories: production deviance, property deviance, political deviance, and personal aggression, as shown in figure 1.

Based on this typology, employee fraud falls under organisational dimension of deviant behaviour. On the basis of the internal control perspective, Well's Taxonomy of Occupation Fraud Schemes (cited by Wright, Johnson \& Dorr, 2006) consist of:

(i) fraudulent statements (financial and non-financial)

(ii) corruption (e.g. economic extortion, illegal gratuities, conflict of interest, and bribery)

(iii) asset misappropriations (e.g. check tampering, expense reimbursement schemes, cash larceny, and misuse of non-cash assets).

The employer-employee relationship is best described by the agency theory. Agency theory holds that both employee (agents) and employer (principal) are utility maximisers (Godfrey, Hodgson \& Holmes, 2000). Both employer and employee are therefore prone to opportunism (Shapiro, 2005). Employees (agents) will behave opportunistically (deviance) if given the chance. Nonetheless, employers (principals) can reduce deviant behaviours if proper monitoring and controlling mechanisms are installed (Kidder, 2005). Since the control environment has been previously found to influence employee fraud, it is therefore believed that the control environment may also have significant influence towards counter-productive behaviours.

Tobin (2000) examined the effects of organisational structure on aggression and violence in the workplace. For organisational aggression and violence, result of the study revealed that organisational factors interact with other behavioural determinants, such as personality and individual affectivity. Through a literature review, it was submitted that structural characteristics can lead to deviant behaviour when there is an incongruence of needs/expectations and environment between the individual and the organization. According to the findings also, individuals progress along a frustration -violence continuum until intervening action is taken by the individual or the organization to overcome obstacles to goals or expectations.

In a separate study, Vardi (2001) examined the ethical climate that was prevalent in a metal-products company that employed 138 individuals, and submitted there was a strong negative relationship between the ethical climate of the organization and the "organizational misbehaviour" that was observed. Organizational misbehaviour was defined as "any intentional action by members of organizations that defies and violates shared organizational norms and core societal values" (Vardi, 2001). In addition, regression analysis revealed that ethical climate has more of an immediate impact on behaviour than overall organizational climate (Vardi, 2001).

Peterson (2002) conducted a study to determine whether deviant workplace behaviour could possibly be predicted from the ethical climate of an organization. Once again, the Ethical Climate Questionnaire (ECQ) was used to determine the ethical climate of organizations of the respondents. In order to determine workplace deviance, a survey was conducted, similar to that used by Robinson and Bennett (1995a, b), which included three items from each of the four classifications described above. The results that Peterson (2002) obtained indicated several correlations between the type of deviance and the climate identified in the organization. The clearest relationship was between Political Deviance and a Caring climate. The implication is that when employees feel 
that the organization is concerned with the welfare of its workers, they are less likely to experience, or engage in, Political Deviance (Peterson, 2002).

Lee and Allen (2002) investigated the role of affect and cognitions in predicting Organizational Citizenship Behavior (OCB) and Workplace Deviance Behavior (WDB), data were collected from 149 registered nurses and their coworkers. Job affect was associated more strongly with OCB directed at individual than were job cognitions, whereas job cognitions correlated more strongly than did job affect. With respect to WDB, job cognitions played a more important role in prediction when job affect was represented by 2 general mood variables (positive and negative affect). When discrete emotions were used to represent job affect, however, job affect played as important a role as job cognition variables, thus strongly suggesting the importance of considering discrete emotions in job affect research.

Galperin (2002) conducted an empirical analysis that examines the relationship between deviance and individual, job, organisational, and cultural factors as determinants of deviance in the workplace, among six hundred and eighty-eight workers. The study proposed that the extent to which people feel confident in performing their roles would have an impact on the relationship between job factors and workplace deviance. It was hypothesised that the role breadth self-efficacy both moderates and mediates the relationship between job autonomy and deviant behaviour. Results of the study generally indicated support for the hypotheses relating to individual, job, and organisational factors.

Maureen, Ambros, Mark, Seabright \& Schminke (2002) examined the relationship between injustice and workplace sabotage. Drawing on the organizational justice and workplace deviance literatures, they hypothesize that injustice will be the most common cause of sabotage, and that the source of injustice will influence the goal, target, and severity of sabotage behavior. The results generally support their hypotheses. First, injustice was the most common cause of sabotage. Second, when the source of injustice was interactional, individuals were more likely to engage in retaliation, and when the source of injustice was distributive, individuals were more likely to engage in equity restoration. Third, the source of injustice and the target of sabotage were generally the same, although this relationship was stronger for organizational targets than for individual targets. They concluded that there was an additive effect of distributive, procedural, and interactional justice on the severity of sabotage.

Lucas \& Friedrich (2005) investigated individual differences in workplace Deviance and integrity as predictors of academic dishonesty college teachers. As reported, literature on deviance correlates and workplace integrity testing demonstrates that individual difference variables can be relatively strong predictors of a range of counter-productive work behaviours. Appelbaum, Laconi \& Matousek (2007) also examined the impact of negative workplace deviant behaviours (those that violate organisational norms, policies or internal rules and positive workplace deviant behaviours (those that honorably violate them) on organization. Results showed that regardless of whether negative deviance is overt or implicit, it has negative consequences for the entity and its affiliates.

Browning (2009) conducted an exploratory study into deviant behaviour among service encounter front-line employees. The findings of the study indicated that the customer's attitude and behaviour are key factors that influence front-line employees to engage in acts of deviance. Muafi (2011) examined the causes and consequence of deviant workplace behavior. Using a sample of 101 operational staff, the results showed that: (a) intent to quit, dissatisfaction and company contempt have positive effect on deviant workplace behavior, (b) dissatisfaction had positive effect on intent to quit, and (c) deviant workplace behavior had negative effect on individual performance. Further, the results suggest that deviant workplace behaviour has high implications for organization even in manufacturing firms.

Anwar, Sarwar, Awan and Aif (2011) investigated gender differences in workplace deviant behaviour among fifty lecturers of post graduate level were selected randomly for the sample. Of these respondents 26 were male and 24 were female. The results of this study reveal that the ratio of organization deviance in the university's workplace is more dominant as compared to interpersonal deviance and the male teaching staffs is more deviant at workplace as compared to female teaching staff.

Omar, Halim, Zainah, Farhadi, Nasir \& Kairudin (2011) investigated the relationship between workplace deviant behaviour and other work-related stress and job satisfaction. Data were collected from 162 participants who were working as civil servants in different sectors. The results showed that both job stress and satisfaction predicted workplace deviant behaviour. A significant positive relationship between stress and workplace deviant behaviour was established. However, the study could not find significant relationship between gender, marital status and workplace deviant behaviour. In view of the wide scope coverage of workplace deviant behaviour, the current the current study investigated the relationship between reactions of workers to existing organizational climate 
and the incidence of deviant and fraudulent behaviours in the workplace. In order to accomplish this objective six hypotheses were formulate:

1) Deviant behaviours of males will be significantly different from that of their female counterpart.

2) There is a significant negative relationship between employees organisational reactions and production deviance in the workplace

3) There is a significant negative relationship between employee's organisational reactions and personal aggression in the workplace

4) There is a significant negative relationship between employee's organisational reactions and political deviance in the workplace

5) There is a significant negative relationship between employee's organisational reactions and property deviance in the workplace.

6) Male workers working in either controlled or less controlled organisations will report more deviant behaviours that their female counterparts.

\section{Methods}

\subsection{Participants}

Data were collected from 696 workers in various public and private organizations in Lagos Metropolis, Nigeria. The organizations were in various industries (e.g. communication, financial, advertising, construction, energy, manufacturing, transportation and administration). A total of 301 (43.2\%) respondents were males, 395 (56.8\%) were females. In the sample, $36 \%$ of the workers were aged $18-23$ years, $21 \%$ of $24-30$ years, $26.3 \%$ were $31-42$ years and $19.8 \%$ aged 43years or above. The average age and job tenure was 32.2 and 6.8 years respectively. A total of 720 questionnaires were distributed, 696 returned (96.6\%) with 26 not properly completed, giving a response rate of $96.6 \%$. The responses were received over a period of two years. The demographics and employment distribution of respondents is presented in Table 1.

\subsection{Design}

A correlational design was used for the study.

\subsection{Instrument}

Five instruments were employed for the study:

1) Workplace deviance was measured by Measures of Workplace Deviance (MDW) developed by R.J Bennett and S.L Robinson (2000). The items on the scale were adapted and used to measure workplace deviant behaviours of participants. MWD is a measure that is specifically designed to assess Workplace deviant behaviours among workers. It is a 28 -items scale, which comprises of 12 -items for organisational deviance (deviant behaviours directed to the organization), and a 16 -items for interpersonal deviant scale (deviant directly harmful to other individuals within the organisation). The authors (Bennett \& Robinson, 2000) reported a coefficient of internal reliabilities of .81 and .78 respectively. Bennett \& Robinson (2000) correlated scores on MWD with Lehman \& Simpson (1992) measure of psychological withdrawal to obtain a coefficient of convergent validity of .65 and .40 respectively for the two subscales. Further, Bennett \& Robinson (2000) obtained a discriminant validity of -.21 and -.13 respectively, by correlating the scores on MWD measures with Farrel \& Rusbult (1986) measures of job loyalty. In order make sure that the instrument conform to local usage, the construct validity of the items was established through the use of factor analysis. The principal component analysis was employed and varimax rotation was applied. The factor analysis for 28 adapted items produced four factors with the total variance explained of $80.35 \%$ (Keiser-Meyer0Olkin measure of sampling adequacy was considered acceptable at 0.856 ). Factor loadings of 0.40 and above were considered as practically significant (Hair, Tatham, Anderson \& Black, 1998). The first factor (production deviance) consists of 12 items with estimated Cronbach's alpha of 0.807. The second factor (Personal aggression) consists of 8 items with Cronbach's alpha of 0.739 . The third and the fourth factors (political and property deviance) consist of 5 and 3 items with Cronbach's alpha of 0.739 and 0.678 , respectively.

2) Perceived control environment was measured by 12 -item questionnaire adapted from the original version developed by Ahmad amd Norhashim (2008). Response range from 1, strongly disagree to 5 strongly agree. The higher the rating denotes favourable perceptions towards the control environment. Ahmad \& Norhashim (2008) reported a Cronbach's alpha reliability coefficients of 0.798 . 
3) Index of Organisational reactions was measured by a 42-items inventory developed by F.J. Smith (1976). IOR Scale was designed to assess eight different kinds of specific job satisfaction in work organization (i.e. supervision, company identification, kind of work, amount of work, co-workers, physical work condition, and financial rewards). In a way, the inventory assesses the reactions of workers to existing organizational climate. Dunham, Grube \& Castaneda (1994) and Mogaji (1997) obtained test -retest (of 6 weeks) reliabilities .62 to .76 and .71 to .99 (72 days) coefficient of reliabilities respectively. Both Dunham et al (1974) and Mogaji (1997) obtained concurrent validity coefficients by correlating six scales of IOR with the appropriate subscales of Job Description Index by Smith et al (1969).

\subsection{Procedures}

Data were gathered through personally administered questionnaire using accidental sampling at workplaces and employed students of professional master degree programme in MPIA (Masters in Pubic and International Affairs), MMP (Managerial Psychology) and MPA (Masters of Public Administration) of the faculty of social sciences, University of Lagos, Nigeria. Participation in the survey was strictly voluntary and anonymous. The permission of unit heads and lecturers of the professional students, as well as the cooperation of workers and professional students were sought. Thereafter, instructions to the completion of the questionnaire were given and the questionnaires were distributed. The questionnaire included items to measure workplace deviance, employee's fraudulent behaviours, and perceived control environment scale. In addition to the items to measure the independent and dependent variables, demographics were also included, such as age, gender, highest level of education and job cadre. Out of the 696 questionnaires, 297 were administered personally at workplaces through some HR Managers. The rest 399 were administered among employed students of professional master degree programmes in University of Lagos. Participants were briefed about (i) the purpose of the questionnaire (ii) anonymity and confidentiality of their response (iii). Participants were assured that the instrument is not a test; therefore, there were no right or wrong answers. The overall response rate of the questionnaires used in the analyses was $62 \%$ (ranging from $43 \%$ to $79 \%$ in the different work groups).

\section{Results}

The first task was to establish statistically whether there were significant gender differences in the incidence of workplace deviant behaviours. In order to achieve this, independent t-test comparison of mean difference of participant's scores on all measures was computed. The result of this is presented in Table 2.

\section{Table 2: Independent t-test Comparison of Mean Difference by Gender for all Measures}

Table 2 shows the mean and standard deviations of participant's scores in all measures of deviant and fraudulent behaviours by gender. As indicated, results in the table show significant t-ratios for the mean difference between male and female on all measures. These results implied that male participants were significantly different as compared to their female counterparts in terms production deviance and personal aggression, respectively. Mean scores of females were higher and significantly different from that of males in production deviant behaviour (mean $=35.60 ; \mathrm{SD}=5.22$; and mean $=31.91 ; \mathrm{SD}=9.41)$ and personal aggression $($ mean $=16.15 ; \mathrm{SD}$ $=6.81$; and mean $=13.66 ; \mathrm{SD}=5.73)$. Similarly, female mean scores were higher and significantly different from that of males in political deviant behaviours (mean $=8.03 ; \mathrm{SD}=3.50$; and mean $=7.40 ; \mathrm{SD}=3.02)$. There results have profound management implication. Male workers mean fraudulent behaviour was higher and significantly different from that of their female counterpart.

In order to examine the influence of employees' reaction to organisational climate on workplace deviant behaviours, a series of multiple regression analyses were computed, using various deviant behaviours as dependent variables as presented in Table 3. The following models describe each regression analysis for each dependent variable. The models indicate the standardized regression weight (Beta), the standard error of estimate (SEB), the degree of freedom (df), the t-ratios and the level at which the t-ratios are significant.

\section{(a) Model1: organisational climate as predictor of production deviance}

Table 3: Summary of regression analysis showing relative contributions of predictor variables to the prediction of production deviance

Prediction of production deviance was explored as presented in the results in Table 4, Result revealed that production was a function employee's reaction to supervision, kinds of work, amount of work, uncertainty of career future and poor financial rewards. As indicated the t-ratio of each of these variables were significant at 0.05 levels. The coefficients of regression analysis shows significant $R^{2}$ of $0.198(F=21.210$, at $p<.05)$, which implies that these variables jointly accounted for about $19.8 \%$ of the observed variance in employee production deviance. The result supports hypothesis 2 . 


\section{(b) Model 2: organisational climate as predictor of personal aggression}

Table 4: Summary of regression analysis showing relative contributions of predictor variables to the prediction of personal aggression

Similarly, prediction of employee personal aggression was examined as presented in the results in Table 4 . Result showed that poor supervision, lack of company identification, the kinds of work people do and uncertainty of career future significantly predict personal sggression at work. As indicated, the t-ratio of each of these variables was significant at 0.05 levels for personal aggression. The coefficients of regression analysis also shows significant $\mathrm{R}^{2}$ of $0.13 .1(\mathrm{~F}=12.993$, at $\mathrm{p}<.05)$, which implies that these variables jointly accounted for about $13.1 \%$ of the observed variance in employee employee aggressive behaviours in the workplace. The result supports hypothesis 3.

\section{(c) Model 3: organisational climate as predictor of political deviance}

Table 5: Summary of regression analysis showing relative contributions of predictor variables to the prediction of political deviance

Further, Table 5 examines the relative contributions of the predictor variables to the prediction of employee political deviance behaviours in the workplace. Like the previous results, results indicated that supervision, company identification, kinds of work, co-workers, physical work conditions and career future were significant predictors of workplace political deviance. The result implies that these organisational reactions variables accounted for about $17.8 \%$ of the observed variance in employee political deviance behaviour, thus confirming the assumption in hypothesis 4.

\section{(d) Model 4: organisational climate as predictor of property deviance}

Table 6: Summary of regression analysis showing relative contributions of predictor variables to the prediction of property deviance

Prediction of property deviance was investigated as presented in the results in Table 6. Result showed that property deviance is a function employee's reaction to their organization (lack of company identification), amount of work, poor financial rewards and uncertainty of career future. As indicated the t-ratio of each of these variables were significant at 0.05 levels. The coefficients of regression analysis shows significant $R^{2}$ of 0.055 $(\mathrm{F}=4.982$, at $\mathrm{p}<.05)$, which implies that these variables jointly accounted for about $5.5 \%$ of the observed variance in employee property deviance. The result supports hypothesis 5 .

Further, influence of gender and organisational deviance and fraudulent behaviour control mechanisms on employee fraudulent behaviours was examined. In order to achieve this, a two-factor between-subject effect was computed by implementing $2 \times 2$ factorial analysis of variance. The result of this computation is presented in Table 7.

Table 7: 2x2 ANOVA Summary Table of Test of Between-Subject Effects of Gender and Work Environment Control Mechanism to the prediction of Workplace Deviant behaviour

Table 7 presents the result of two-factor ANOVA computed to determine the significance of main and interaction influence of gender and work environment control mechanism on deviant behaviour. The result as presented shows that employee gender, combined with environmental control did not significantly influence the incidence of deviant behaviour among the sampled employees under investigation.

Table 8: Mean and Standard Deviations of Main Influence of Gender and Work Environment Fraudulent Behaviour Control Mechanisms

As indicated in Table 8, mean deviant behaviours of female at both controlled work environment and permissive work environment (mean $=51.44 ; \mathrm{SD}=17.64$, and mean $=54.77 ; \mathrm{SD}=20.14)$ was higher than that of their male counterparts (mean $=43.83 ; \mathrm{SD}=12.10$, and mean $=52.81 ; \mathrm{SD}=15.46)$ even tough not significantly different. Main influence of gender and work environment control was not significant. Likewise, interaction between gender and work environment control was not significant as expected.

\section{Discussions}

Hypothesis 1 which stated that there is a significant negative relationship between employee's organisational reactions and personal aggression in the workplace is accepted except for career future. Results show that employee aggressive behaviour is a function of bad supervision, lack of company identification, poor co-workers relationships and poor physical work condition. The coefficient of regression analysis shows that these variables jointly accounted for about $13.1 \%$ of the observed variance in employee aggressive behaviours in the workplace. 
The result is consistent with Tobin (2000) which reported that organisational factors interact with other behavioural determinants. According to the finding, individual progress along a frustration-violence continuum until intervening action is taken by the individual or the organization to overcome obstacles to goals or expectations.

Hypothesis 2 which stated that there is a significant negative relationship between employee's organisational reactions and political deviance in the workplace was accepted. Result revealed that political deviance was higher when supervision and company identification was poor, when amount of work, physical work condition and co-workers relationship is demeaning. The variables together accounted for about $17.8 \%$ of the observed variance in employee political deviance behaviour. This is consistent with the findings of Galperin (2002) which suggested that the extent to which people feels confident in performing their roles would have an impact on the relationship between job factors and workplace defiant behaviours.

Hypothesis 3 which stated that there is a significant negative relationship between employee's organisational reactions and property deviance in the workplace is accepted. Result showed that property deviance is a function employee's reaction to poor supervision, lack of company identification, strained co-worker relationships, poor financial rewards and uncertainty of career future. These variables as indicated, jointly accounted for about 5.5\% of the observed variance in employee property deviance. This result corresponds well with Maureen, Ambros, Mark, Seabright \& Schminke (2002) which examines the relationship between injustice and workplace sabotage. Result revealed that injustice will influence the goal, target, and severity of sabotage behavior. Also they find out that when injustice was interactional, people become more likely to engage in retaliation, and when the source of injustice was distributive, individuals will be more likely to engage in equity restoration. They concluded that there was an additive effect of distributive, procedural, and interactional justice on the severity of sabotage. The result amplify the finding of Lucas and Friedrich (2005) and that of Appelbaum, Laconi and Matousek (2007) which reported that negative deviant behaviours have negative organisational consequences, whether it is overt or implicit. The study thus conclude that workplace integrity testing demonstrate that individual difference variables can be relatively strong predictors of a range of counter-productive workplace behaviours.

Hypothesis 4 Male workers working in either controlled or permissive work environment organisations will report more deviant behaviours that their female counterpart was rejected. Result showed that employee gender did significantly influences the incidence of deviant behaviour among the sampled employees under investigation. Deviant behaviours reported by female employees at both perceived controlled work environment and permissive work environment was higher than that of their male counterpart. This result is not consistent with the findings of Anwar, Sarwar, Awan and Arif (2011) which submitted that the ratio of organization deviance in the university's workplace is more dominant as compared to interpersonal deviance and the male teaching staff is more deviant at workplace as compared to female teaching staff.

The result extended the findings of Lucas \& Friedrich (2005) which investigated individual differences in workplace deviance and integrity as predictors of dishonesty. It further amplified the issues already reported in literature that deviance correlates positively with workplace integrity testing. Also, their finding demonstrates that individual difference variables are relatively strong predictors of a range of counter-productive work behaviours in the workplace.

\section{Conclusion}

This study examined the individual and organisational determinants of workplace deviant behaviours in the organizational workgroup setting. In particular, we focused on organisational climate as well as group member's affectivity. The results suggested that the strength of interpersonal affectivity moderated the relationship between organisational reactions and deviant behaviours. Also, high level negative reactions exacerbated workplace fraudulent behaviours for male group members, compare to female members. We consider this result to be of great importance for managers who seek to understand management implications of industrial workplace sabotage and deviant behaviours in organisations.

In order to reduce or eliminate workplace deviance to enhance business security, managers need to consider the employees reactions to organisational policies and practice, as well as the views members hold and what attract them most to the organisation. If the member's reaction to organisational practices is positive, they will be likely attracted by the harmonious relationships maintained in the workgroup. Consequently, group members may engage in deviant behaviour as a way to ventilate their dissatisfaction with the organisation or simply to retaliate upon their peers. In order to avoid this situation, managers need to build a trusting environment. When group members show high positive reactions to their organisations they tend to perform their jobs better with little or no supervision, as suggested by our findings. 


\section{References}

Ahmad, Z., \& Norhashim, M. (2008). The control environment, employee fraud and counterproductive workplace behaviour: An empirical analysis. Communications of the IBMA, 3 145-151.

Akinbode, G.A. (2009). Effects of gender and organisational factors on workplace deviant and fraudulent behaviours. Journal of Management and Entrepreneur, 2(1), 53-79.

Anwar, M.N., Sarwar, M., Awan, R.N., \& Arif, M.I. (2011). Gender differences in workplace deviant behaviour of university teachers and modification techniques. International Education Studies, 4(1). Published by Canadian Center for Science Education.

Appelbaum, S.H., Laconi, G.D., \& Matousek, A. (2007). Positive and negative deviant workplace behaviours: Causes, impacts and solutions. Corporate Governance, 7(5), 586-598. http://dx.doi.org/10.1108/14720700710827176

Aquino, K., Lewis, M.U., \& Bradfield, M. (1999). Justice constructs, negative affectivity, and employee deviance: A proposed model and empirical. Journal of Organisational Behaviour, 20(7), 1073-1091. http://dx.doi.org/10.1002/(SICI)1099-1379(199912)20:7<1073::AID-JOB943>3.0.CO;2-7

Bennett, R.J., \& Robinson, S.L. (2000). Development of a measure of workplace deviance. Journal of Applied Psychology, 85(3), 349-360.

Bennett, R.J., \& Robinson, S.L. (2003). The past, present and future of workplace deviance research, In J. Greenberg (Ed.) Organisational behaviour: The state of the science, (2 ${ }^{\text {nd }}$ Ed.) Lawrence Erlbaum. http://dx.doi.org/10.1037/0021-9010.85.3.349

Brief, A.P., \& Weiss, H.M. (2002). Organisational behaviour: affect in the workplace. Annual Review of Psychology, 53, 279-307. http://dx.doi.org/10.1146/annurev.psych.53.100901.135156

Browning, V. (2009). An exploratory study into deviant behaviour in the service encounter: How and why front-line employees engage in deviant behaviour. Journal of Management, 14(4), 451-464.

DePaulo, P.J., \& DePaulo, B.M. (1989). Can deception by salespeople and customers be detected through nonverbal nehavioural cues?, Journal of Applied Social Psychology, 19, 1552-1577. http://dx.doi.org/10.1111/j.1559-1816.1989.tb01463.x

Douglas, S.C., \& Martinko, M.J. (2001). Exploring the role of individual differences in the prediction of $\begin{array}{lllll}\text { workplace aggression. Journal of Applied Psychology, 86, } & \text { 846-859. }\end{array}$ http://dx.doi.org/10.1037/0021-9010.86.4.547

Dunham, R.B., Grube, J.A., \& Castaneda, M.B. (1994). Organisational commitment: The utility of an integrative definition. Journal of Applied Psychology, 79(3), 370-380. http://dx.doi.org/10.1037/0021-9010.79.3.370

Farrel, D., \& Rusbult, C. (1986). Measurement of responses to job dissatisfaction: Exit, voice, loyalty and neglect. Unpublished manuscript, Western Michigan University.

Fisher, C.D. (2000). Mood and emotions while working: Missing pieces of job satisfaction?. Journal of Organisational Behaviour, 185-202. http://dx.doi.org/10.1002/(SICI)1099-1379(200003)21:2<185::AID-JOB34>3.0.CO;2-M

Fisher, C.D. (2002). Antecedents and consequences of real-time affective reactions at work. Motivation \& Emotion, 26, 3-30. http://dx.doi.org/10.1023/A:1015190007468

Fisher, C.D. (2003). Why do lay people believe that satisfaction and performance are correlated? Possible sources of a commonsense theory. Journal of Organisational Behaviour, 24, 753-777. http://dx.doi.org/10.1002/job.219

Fisher, D. (1998). Affective events emotions matrix: A classication of work events and associated emotions. In Ashkanasy, N. M., Charmine, E.J. \& Zerbe, W. J. Emotion in the workplace. Greenwood Publishing Inc: West Point, CT.

Fox, S., \& Spector, P.E. (1999). A model of work frustration-aggression. Journal of Organisational Behaviour, 20, 915-913. http://dx.doi.org/10.1002/(SICI)1099-1379(199911)20:6<915::AID-JOB918>3.0.CO;2-6

Fox, S., Spector, P.E., \& Miles, D. (2001). Counterproductive work behaviour (CWB) in response to job stressors and organisational justice: Some mediator and moderator tests for autonomy and emotions. Journal of Vocational Behaviour, 59, (3), 291-309. http://dx.doi.org/10.1006/jvbe.2001.1803 
Galperin, B., \& Burke, R.J. (2006). Uncovering the Relationship between Workaholism and Workplace Destructive and Constructive Deviance: An Exploratory Study. International Journal of Human Resource Management, 17, 331-347. http://dx.doi.org/10.1080/09585190500404853

Galperin, B.L. (2002). Determinants of deviance in the workplace: an empirical examination in Canada and Mexico. Unpublished Ph.D Thesis, Concordia University.

George, J. M., \& Brief, A. P. (1992). Feeling good -- doing good: A conceptual analysis of the mood at work--organizational spontaneity relationship. Psychological Bulletin, 112, 310-329. http://dx.doi.org/10.1037/0033-2909.112.2.310

George, J.M. (1989). Mood and absence. Journal of Applied Psychology, 74, 317 - 324. http://dx.doi.org/10.1037/0021-9010.74.2.317

Godfrey, J., Hodgson, A., \& Holmes, S. (2000). Accounting Theory. John Wiley \& Sons, Inc, Singapore.

Gomez-Mejia, L.R., Wiseman, R.M., \& Dykes, B.J. (2005). Agency problems in diverse contexts: A global $\begin{array}{lllll}\text { perspective. Journal of } & \text { Management } & \text { Studies, } & 42(7), & \text { 1507-1517. }\end{array}$ http://dx.doi.org/10.1111/j.1467-6486.2005.00554.x

Greenberg, J., \& Scott, K. (1996). Why do employees bite the hand that feeds them? Employee theft as a social exchange process. In B.M. Staw and L.L. Cummings Eds.) Research in Organizational Behavior (Vol. 18, pp. 111-155). Greenwich, CT: JAI Press.

Griffin, R.W., \& Y. P. Lopez. (2005). "Bad behavior" in organizations: a review and typology for future research. Journal of Management, 31, 988. http://dx.doi.org/10.1177/0149206305279942

Hair, J.F., Tatham, R., Anderson, R., \& Black, W. (1998). Multivariate data analysis. Upper Saddle River, NJ: Prentice-Hall.

Harper, D. (1990). Spolight abuse-save profits. Industrial distribution, 79, 47-51.

Hollinger, R.C., \& Clark, J.P. (1982). Formal and informal social controls of employees deviance. The Sociological Quraterly, 23, 333-343. http://dx.doi.org/10.1111/j.1533-8525.1982.tb01016.x

Hollinger, R.C., \& Clark, J.P. (1982). Theft by employees. Lexington, MA: D.C. Health.

Hollinger, R.C., and Clark, J.P. (1983). Deterrence in the workplace: Perceived certainty, perceived severity, and employee theft. Social Force, 62(2), 398-417.

Hulin, C. (1991). Adaptation, persistence, and commitment in organizations. In M. D. Dunnette \& L. M. Hough (Eds.), Handbook of industrial and organizational psychology, Vol. 2 (2nd ed.). (445-505). Palo Alto, CA: Consulting Psychologists Press.

Johns, G. (1997). "Contemporary research on absence from work: correlates, causes, and consequences", In Cooper, C.L. and Robertson, I.T. (Eds.), International Review of Industrial and Organisational Psychology, 12, John Wiley \& Sons, London, 115-174.

Kidder, D. L. (2005). It is 'who I am', 'what I can get away with', or 'what you've done to me?' A multi-theory examination of employee misconduct. Journal of Business Ethic, 57(4), 329-398. http://dx.doi.org/10.1007/s10551-004-6713-x

Kidwell, R. E., \& Bennett, N. (1993). Employee propensity to withhold effort: A conceptual model to intersect three avenues of research. Academy of Management Review, 18, 429-456.

Kidwell, R. E., \& Martin, C. L. (2004). Managing the ambiguity of workplace deviance: Lessons from the study of conflict. Paper presented at the meeting of the Academy of Management, New Orleans.

Lee, K., \& Allen, N. J. (2002). Organizational citizenship behavior and workplace deviance: The role of affect and cognitions. Journal of Applied Psychology, 87(1), 131-142. http://dx.doi.org/10.1037/0021-9010.87.1.131

Lehman, W., \& Simposn, D. (1992). Employee substance abuse and on-the-job behaviours. Journal of Applied Psychology, 77, 309-321. http://dx.doi.org/10.1037/0021-9010.77.3.309

Lucas, G.M., \& Friedrich, J. (2005). Individual differences in workplace deviance and integrity as predictors of academic dishonesty. Ethics and Behaviour, 15(1), 15-35. http://dx.doi.org/10.1207/s15327019eb1501_2

Maureen, Ambros, Mark, Seabright \& Schminke (2002). Sabotage in the workplace:The role of organisational injustice. Organisational Behaviour \& Human Decision Processes, 89(1), 949-965. 
Mogaji, A.A. (1997). "Effect of organisational climate on employees commitment, involvement and motivation in some Nigerian manufracturing industries." Unpublished Ph.D Thesis, Dept. of Psychology, University of Lagos.

Mowday, R.T., Porter, L.W., \& Steers, R.M. (1982). Employee-organization linkages: The Psychology of Commitment, Absenteeism, and Turnover. New York: Academic Press

Muafi, J. (2011). Causes and Consequences of devant workplace behavior. International Journal of Innovation, Management and Technology, 2(2), 123-126.

Murphy, K.R. (1993). Honesty in the workplace. Belmont, CA: Brooks/Cole

Omar, Halim, Zainah, Farhadi, Nasir \& Kairudin. (2011). Stress and job satisfaction as antecedents of workplace deviant behavior. World Applied Sciences Journal, 12, 45-51.

Organ, D. W. (1988). A restatement of the satisfaction-performance hypothesis. Journal of Management, 14, 547-557. http://dx.doi.org/10.1177/014920638801400405

Peterson. (2002). Deviant workplace behaviour and the organisation's ethical climate. Journal of Business and Psychology, 17(1).47-56.

Robinson, S. L., \& Bennett, R. J. (1995). A typology of deviant workplace behaviors: A multidimensional scaling study. Academy of Management Journal, 38(2), 555-572. http://dx.doi.org/10.2307/256693

Shapiro, S. P. (2005). Agency Theory. Annual Review of Sociology, 31(1), 263-284. http://dx.doi.org/10.1146/annurev.soc.31.041304.122159

Skarlicki and Folger. (1997). Retaliation in the workplace: the roles of distributive, procedural, and interactional justice. Journal of Psychology, 82, 416-425.

Skarlicki, D. P., Folger, R., \& Tesluk, P. (1999). Personality as a moderator in the relationship between fairness and retaliation. Academy of Management Journal, 42, 100-108. http://dx.doi.org/10.2307/256877

Smith, P. C., Kendall, L., \& Hulin, C. L. (1969). The measurement of satisfaction in work and retirement. Chicago: Rand McNally.

Smith, P.C. (1976). Index of organisational reactions (IOR). JSAS Catalog of Selected Documents in Psychology, 6(1), 54 No. 1265.

Tobin, T.J. (2000). Organisational determinants of violence in the workplace. Aggression and Violent Behaviour, 6(1), 91-102. http://dx.doi.org/10.1016/S1359-1789(00)00011-2

Vardi, Y. (2001). The effects of organisational and ethical climates on misconduct at work. Journal of Business Ethics, 29, 325-327. http://dx.doi.org/10.1023/A:1010710022834

Vardi, Y., \&Wiener, Y. (1996). Misbehavior in organizations: A motivational framework. Organization Science, 7, 151-165. http://dx.doi.org/10.1287/orsc.7.2.151

Weiss, H.M. (2002). Deconstructing job satisfaction: Separating evaluations, beliefs and affective experiences. Human Resource Management Review, 12, 173 - 194.

Weiss, H.M., \& Cropanzano, R. (1996). Affective Events Theory: A theoretical discussion of the structure, causes and consequences of affective experiences at work. JAI Press, Greenwich, CT, 1 - 74. http://dx.doi.org/10.1016/S1053-4822(02)00045-1

Wright, C.J., Johnson, C.B., \& Dorr, P.B. (2006). Employee recognition and assessment of fraud schemes: An international perspective. Petroleum Accounting and Financial Management Journal, 25(1), 17-40. 
Table 1. Respondents' demographics

\begin{tabular}{|c|l|c|c|}
\hline Demographics & \multicolumn{1}{|c|}{ Categories } & N & \%age \\
\hline & Male & 301 & 43.2 \\
Gender & Female & 395 & 56.8 \\
\hline Highest & HND/Degree & 696 & 100 \\
Academic & MSc/MBA & 119 & 17.1 \\
Qualification & Professional (others) & 207 & 29.7 \\
\hline \multirow{3}{*}{ Job position } & Junior Officer & 216 & 31.0 \\
& Senior Executives & 246 & 35.3 \\
& Mgt-executive & 234 & 33.6 \\
\hline Organisational type & Private & 418 & 60.1 \\
& Public & 278 & 39.9 \\
\hline
\end{tabular}

Table 2. Independent t-test Comparison of Mean Difference by Gender for all Measures

\begin{tabular}{|c|c|c|c|c|c|c|c|}
\hline $\begin{array}{l}\text { Variable } \\
\text { Category }\end{array}$ & Gender & $\mathrm{N}$ & Mean & $\begin{array}{c}\text { Std. } \\
\text { Deviation }\end{array}$ & df & Tcal & pv \\
\hline \multirow{2}{*}{$\begin{array}{l}\text { Production } \\
\text { Deviance }\end{array}$} & Male & 301 & 31.91 & 9.41 & \multirow[b]{2}{*}{694} & \multirow[b]{2}{*}{-6.582} & \multirow[b]{2}{*}{$\mathrm{P}<0.05$} \\
\hline & Female & 395 & 35.60 & 5.22 & & & \\
\hline \multirow{2}{*}{$\begin{array}{l}\text { Personal } \\
\text { Aggression }\end{array}$} & Male & 301 & 13.66 & 5.73 & \multirow[b]{2}{*}{694} & \multirow[b]{2}{*}{-5.112} & \multirow[b]{2}{*}{$\mathrm{P}<0.05$} \\
\hline & Female & 395 & 16.15 & 6.81 & & & \\
\hline \multirow{2}{*}{$\begin{array}{l}\text { Political } \\
\text { Deviance } \\
\end{array}$} & Male & 301 & 7.40 & 3.02 & \multirow[b]{2}{*}{694} & \multirow[b]{2}{*}{-2.616} & \multirow[b]{2}{*}{$\mathrm{P}<0.05$} \\
\hline & Female & 395 & 8.03 & 3.50 & & & \\
\hline \multirow{2}{*}{$\begin{array}{l}\text { Property } \\
\text { Deviance }\end{array}$} & Male & 301 & 6.44 & 2.32 & \multirow[b]{2}{*}{694} & \multirow[b]{2}{*}{-1.970} & \multirow[b]{2}{*}{$\mathrm{P}<0.05$} \\
\hline & Female & 395 & 6.82 & 2.64 & & & \\
\hline
\end{tabular}

(a) Modell: organisational climate as predictor of production deviance

Table 3. Summary of regression analysis showing relative contributions of predictor variables to the prediction of production deviance

\begin{tabular}{|c|c|c|c|c|c|c|c|c|c|}
\hline \multirow[t]{2}{*}{ VARIABLES } & \multicolumn{2}{|c|}{$\begin{array}{l}\text { Unstandardised } \\
\text { Coefficients }\end{array}$} & \multirow{2}{*}{$\begin{array}{c}\text { Standardised } \\
\text { Coefficients } \\
\text { Beta } \\
\end{array}$} & \multirow[t]{2}{*}{ t-ratio } & \multirow[t]{2}{*}{ Sig. } & \multirow[t]{2}{*}{$\mathrm{R}$} & \multirow[t]{2}{*}{$\mathrm{R}^{2}$} & \multirow[t]{2}{*}{ F-ratio } & \multirow[t]{2}{*}{$\mathrm{Pv}$} \\
\hline & $\mathrm{B}$ & Std. Error & & & & & & & \\
\hline Supervision & -.468 & .074 & -.245 & -6.367 & $\mathrm{P}<.05$ & \multirow{8}{*}{.445} & \multirow{8}{*}{.198} & \multirow{8}{*}{21.210} & \multirow{8}{*}{$\mathrm{P}<.05$} \\
\hline $\begin{array}{l}\text { Company } \\
\text { Identification }\end{array}$ & -.005 & .085 & -.025 & -.660 & $\mathrm{p}>.05$ & & & & \\
\hline Kinds of Work & .485 & .072 & .236 & 6.726 & $\mathrm{P}<.05$ & & & & \\
\hline Amount of Work & .658 & .088 & -.275 & -7.481 & $\mathrm{P}<.05$ & & & & \\
\hline Co-Workers & .223 & .094 & .093 & 2.384 & $\mathrm{P}<.05$ & & & & \\
\hline $\begin{array}{l}\text { Physical Work } \\
\text { Conditions }\end{array}$ & .128 & .088 & .051 & 1.460 & $\mathrm{p}>.05$ & & & & \\
\hline Financial Rewards & .276 & .102 & .097 & 2.707 & $\mathrm{P}<.05$ & & & & \\
\hline Career Future & .438 & .079 & .193 & 5.563 & $\mathrm{P}<.05$ & & & & \\
\hline
\end{tabular}

Dependent variable: Production Deviance

(b) Model 2: organisational climate as predictor of personal aggression 
Table 4. Summary of regression analysis showing relative contributions of predictor variables to the prediction of personal aggression

\begin{tabular}{|c|c|c|c|c|c|c|c|c|c|}
\hline \multirow[t]{2}{*}{ VARIABLES } & \multicolumn{2}{|c|}{$\begin{array}{l}\text { Unstandardised } \\
\text { Coefficients }\end{array}$} & \multirow{2}{*}{$\begin{array}{c}\begin{array}{c}\text { Standardised } \\
\text { Coefficients }\end{array} \\
\text { Beta }\end{array}$} & \multirow[t]{2}{*}{ t-ratio } & \multirow[t]{2}{*}{ Sig. } & \multirow[t]{2}{*}{$\mathrm{R}$} & \multirow[t]{2}{*}{$\mathrm{R}^{2}$} & \multirow[t]{2}{*}{ F-ratio } & \multirow[t]{2}{*}{ pv } \\
\hline & $\mathrm{B}$ & Std. Error & & & & & & & \\
\hline Supervision & -304 & .066 & -.185 & -4.630 & $\mathrm{P}<.05$ & \multirow{8}{*}{.363} & \multirow{8}{*}{.131} & \multirow{8}{*}{12.993} & \multirow{8}{*}{$\mathrm{P}<.05$} \\
\hline Company Identification & -.375 & .076 & -.195 & -4.939 & $\mathrm{P}<.05$ & & & & \\
\hline Kinds of Work & -.122 & .064 & -.069 & -1.892 & $\mathrm{P}<05$ & & & & \\
\hline Amount of Work & -.111 & .079 & -.054 & -1.410 & $\mathrm{p}>.05$ & & & & \\
\hline Co-Workers & -.001 & .084 & -.005 & -.126 & $\mathrm{p}>.05$ & & & & \\
\hline Physical Work Conditions & .002 & .078 & .011 & .310 & $\mathrm{p}>.05$ & & & & \\
\hline Financial Rewards & .000 & .091 & .000 & .011 & $\mathrm{p}>.05$ & & & & \\
\hline Career Future & .437 & .070 & .225 & 6.216 & $\mathrm{P}<.05$ & & & & \\
\hline
\end{tabular}

Dependent variable: Personal Aggression

(c) Model 3: organisational climate as predictor of political deviance

Table 5. Summary of regression analysis showing relative contributions of predictor variables to the prediction of political deviance

\begin{tabular}{|c|c|c|c|c|c|c|c|c|c|}
\hline \multirow[t]{2}{*}{ VARIABLES } & \multicolumn{2}{|c|}{$\begin{array}{c}\text { Unstandardised } \\
\text { Coefficients }\end{array}$} & \multirow{2}{*}{$\begin{array}{c}\text { Standardised } \\
\text { Coefficients }\end{array}$} & \multirow[t]{2}{*}{ t-ratio } & \multirow[t]{2}{*}{ Sig. } & \multirow[t]{2}{*}{$\mathrm{R}$} & \multirow[t]{2}{*}{$\mathrm{R}^{2}$} & \multirow[t]{2}{*}{ F-ratio } & \multirow[t]{2}{*}{ pv } \\
\hline & $\mathrm{B}$ & Std. Error & & & & & & & \\
\hline Supervision & -.009 & .033 & -.107 & -2.749 & $\mathrm{P}<.05$ & \multirow{8}{*}{.422} & \multirow{8}{*}{.178} & \multirow{8}{*}{18.620} & \multirow{8}{*}{$\mathrm{P}<.05$} \\
\hline Company Identification & -.204 & .038 & -.207 & -5.393 & $\mathrm{P}<.05$ & & & & \\
\hline Kinds of Work & -.143 & .032 & -.159 & -4.483 & $\mathrm{P}<.05$ & & & & \\
\hline Amount of Work & -.004 & .039 & -.044 & -1.169 & $\mathrm{p}>.05$ & & & & \\
\hline Co-Workers & -.007 & .042 & -.075 & -1.897 & $\mathrm{P}<.05$ & & & & \\
\hline Physical Work Conditions & -.178 & .039 & -.163 & -4.578 & $\mathrm{P}<.05$ & & & & \\
\hline Financial Rewards & .008 & .045 & .068 & 1.873 & $\mathrm{p}>.05$ & & & & \\
\hline Career Future & .216 & .035 & .217 & 6.175 & $\mathrm{P}<.05$ & & & & \\
\hline
\end{tabular}

Dependent variable: Political Deviance

(d) Model 4: organisational climate as predictor of property deviance

Table 6. Summary of regression analysis showing relative contributions of predictor variables to the prediction of property deviance

\begin{tabular}{|c|c|c|c|c|c|c|c|c|c|}
\hline \multirow[t]{2}{*}{ VARIABLES } & \multicolumn{2}{|c|}{$\begin{array}{c}\text { Unstandardised } \\
\text { Coefficients }\end{array}$} & \multirow{2}{*}{$\begin{array}{c}\begin{array}{c}\text { Standardised } \\
\text { Coefficients }\end{array} \\
\text { Beta }\end{array}$} & \multirow[t]{2}{*}{ t-ratio } & \multirow[t]{2}{*}{ Sig. } & \multirow[t]{2}{*}{$\mathrm{R}$} & \multirow[t]{2}{*}{$\mathrm{R}^{2}$} & \multirow[t]{2}{*}{ F-ratio } & \multirow[t]{2}{*}{$\mathrm{pv}$} \\
\hline & B & Std. Error & & & & & & & \\
\hline Supervision & .001 & .027 & .016 & .394 & $\mathrm{p}>.05$ & \multirow{8}{*}{234} & \multirow{8}{*}{.055} & \multirow{8}{*}{4.982} & \multirow{8}{*}{$\mathrm{P}<.05$} \\
\hline Company Identification & -.005 & .031 & -.079 & -1.918 & $\mathrm{P}<.05$ & & & & \\
\hline Kinds of Work & -.000 & .026 & -.011 & -.285 & $\mathrm{p}>.05$ & & & & \\
\hline Amount of Work & .009 & .032 & .122 & .3 .063 & $\mathrm{P}<.05$ & & & & \\
\hline Co-Workers & -.002 & .034 & -.027 & -.625 & $\mathrm{p}>.05$ & & & & \\
\hline Physical Work Conditions & -.002 & .032 & -.029 & -.761 & $\mathrm{p}>.05$ & & & & \\
\hline Financial Rewards & .115 & .037 & -.122 & -3.135 & $\mathrm{P}<.05$ & & & & \\
\hline Career Future & .007 & .029 & .106 & 2.804 & $\mathrm{P}<.05$ & & & & \\
\hline
\end{tabular}

Dependent variable: Property Deviance 
Table 7. 2x2 ANOVA Smmary Table of Test of Between-Subject Effects of Gender and Work Environment Control Mechanism to the prediction of Workplace Deviant behaviour

\begin{tabular}{|l|l|l|l|l|c|}
\hline \multicolumn{1}{|c|}{ Source } & \multicolumn{1}{c|}{$\begin{array}{c}\text { Type III } \\
\text { Sum of Squares }\end{array}$} & df & \multicolumn{1}{c|}{ Mean Square } & F-ratio & Pv \\
\hline Gender & 512.671 & 1 & 512.671 & 1.769 & $\mathrm{P}>.05$ \\
\hline Work Environmental Control & 846.876 & 1 & 846.876 & 2.922 & $\mathrm{p}>.05$ \\
\hline Gender * Work Environmental Control & 178.753 & 1 & 178.753 & .617 & $\mathrm{p}>.05$ \\
\hline Total & 268103.0 & 88 & & & \\
\hline
\end{tabular}

Table 8. Mean and Standard Deviations of Main Influence of Gender and Work Environment Fraudulent Behaviour Control Mechanisms

\begin{tabular}{|c|c|c|c|c|c|c|c|c|}
\hline \multirow{4}{*}{$\begin{array}{l}\text { Factor (A) } \\
\text { Gender }\end{array}$} & \multicolumn{8}{|c|}{ Factor (B) Work Environment and } \\
\hline & \multicolumn{8}{|c|}{ Workplace Deviant Behaviour Control Mechanisms } \\
\hline & \multicolumn{4}{|c|}{$\begin{array}{l}\left(\mathrm{B}_{1}\right) \text { Controlled } \\
\text { work environment }\end{array}$} & \multicolumn{4}{|c|}{$\begin{array}{l}\left(\mathrm{B}_{2}\right) \text { Permissive } \\
\text { Work Environment }\end{array}$} \\
\hline & Mean & SD & Std. Error & $\mathrm{N}$ & Mean & SD & Std. Error & $\mathrm{N}$ \\
\hline Male $\left(A_{1}\right)$ & 43.83 & 12.10 & 2.85 & 18 & 52.81 & 15.46 & 3.36 & 21 \\
\hline Female $\left(\mathrm{A}_{2}\right)$ & 51.44 & 17.64 & 3.39 & 27 & 54.77 & 20.14 & 3.95 & 26 \\
\hline
\end{tabular}

\begin{tabular}{|c|c|}
\hline \multicolumn{2}{|c|}{ Organisational } \\
\hline $\begin{array}{ll} & \text { Production Deviance } \\
\text { - } & \text { leaving early } \\
\text { - } & \text { absenteeism } \\
\text { - } & \text { taking excessive breaks } \\
\text { - } & \text { intentionally working slowly } \\
\text { - } & \text { wasting resources } \\
\end{array}$ & \begin{tabular}{ll} 
& \multicolumn{1}{c}{ Property Deviance } \\
- & sabotaging equipment \\
- & vandalism \\
- & accepting kickbacks \\
- & lying about hours worked \\
- & stealing from company \\
\end{tabular} \\
\hline Minor & Serious \\
\hline $\begin{array}{ll} & \text { Political Deviance } \\
\text { - } & \text { showing favouritism } \\
\text { - } & \text { spreading rumors } \\
\text { - } & \text { gossiping about co-workers } \\
\text { - } & \text { blamming co-wokers } \\
\text { - } & \text { competing non-beneficially }\end{array}$ & $\begin{array}{ll} & \text { Personal Aggression } \\
\text { - } & \text { sexual harrasment } \\
\text { - } & \text { verbal abuse } \\
\text { - } & \text { physical assault } \\
\text { - } & \text { stealing from co-workers } \\
\text { - } & \text { endangering co-workers }\end{array}$ \\
\hline & \\
\hline
\end{tabular}

Figure 1. Typology of negative deviant workplace behaviour

Source: Muafi, J. (2011). Causes and Consequences of devant workplace behaviour, International Journal of Innovation, Management and Technology, 2(2), 123-126. 